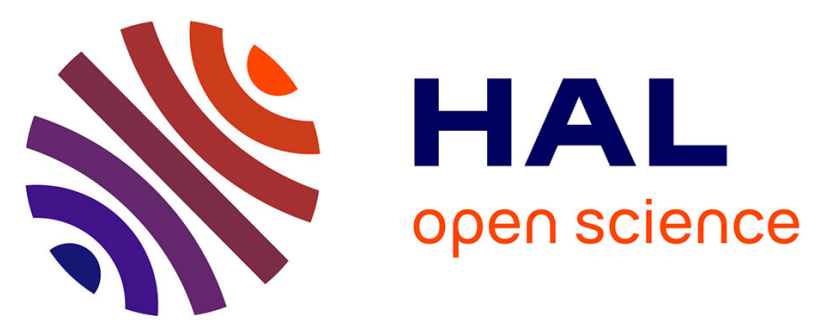

\title{
3D seismic study of a ductile shear zone from laboratory and petrofabric data (Saint Barthélémy Massif, Northern Pyrenees, France)
}

Guilhem Barruol, David Mainprice, Hartmut Kern, Michel de Saint Blanquat, Patrick Compte

\section{To cite this version:}

Guilhem Barruol, David Mainprice, Hartmut Kern, Michel de Saint Blanquat, Patrick Compte. 3D seismic study of a ductile shear zone from laboratory and petrofabric data (Saint Barthélémy Massif, Northern Pyrenees, France). Terra Nova, 1992, 4, pp.63 - 76. 10.1111/j.1365-3121.1992.tb00451.x . hal-01389722

\section{HAL Id: hal-01389722 \\ https://hal.univ-reunion.fr/hal-01389722}

Submitted on 29 Oct 2016

HAL is a multi-disciplinary open access archive for the deposit and dissemination of scientific research documents, whether they are published or not. The documents may come from teaching and research institutions in France or abroad, or from public or private research centers.
L'archive ouverte pluridisciplinaire HAL, est destinée au dépôt et à la diffusion de documents scientifiques de niveau recherche, publiés ou non, émanant des établissements d'enseignement et de recherche français ou étrangers, des laboratoires publics ou privés. 


\title{
3D seismic study of a ductile shear zone from laboratory and petrofabric data (Saint Barthélémy Massif, Northern Pyrénées, France)
}

\author{
Guilhem Barruol*, David Mainprice* , Hartmut Kernt, Michel de Saint Blanquat ${ }^{1}$ and Patrick Compte $\S^{2}$ \\ *Laboratoire Tectonophysique, Université Montpellier II, 34095 Montpellier cedex 5, France; +Mineralogisch-Petrographisches \\ Institut, Olshausenstr. 40, 2300 Kiel, Germany; $\neq$ Laboratoire de Tectonique, Université Montpellier II, 34095 Montpellier cedex 5 , \\ France; §Compagnie Générale de Géophysique, 1 rue L. Migaud, 91302 Massy cedex, France
}

\begin{abstract}
In order to constrain interpretations of seismic reflection records more effectively, the seismic properties of a middle crustal section exposed in the Saint Barthélémy Massif have been determined. The massif, transected by a $200 \mathrm{~m}$ thick shear zone has been systematically sampled for density measurements and modal analysis has been performed in order to define the spatial variations of physical properties. Seismic velocities $\left(V_{p}, V_{s}\right.$, shear wave birefringence), have been measured on five representative samples to $600 \mathrm{MPa}$ and $600^{\circ} \mathrm{C}$ simultaneously in the three structural directions $(X, Y$ and $Z$ ). For two samples, the experimental data have been compared with calculated values, based on petrofabric analyses. The Lattice Preferred Orientation (LPO) is determined using universal stage, electron channelling microscopy and neutron diffraction goniometry. Using the experimental and calculated velocity data, we establish a lateral homogeneous anisotropic model.
\end{abstract}

Terra Nova, 4, 63-76

\section{INTRODUCTION}

Deep seismic profiling of the lower continental crust has revealed many strong reflections. Up to now, their origins have been poorly understood. Lowangle reflections are often interpreted as ductile shear zones, e.g. COCORP and the Brevard Fault (Cook et al., 1979), ECORS-Alps and the Penninic front (Nicolas et al., 1990), ECORS-Pyrenees and the Variscan thrust (Choukroune et al., 1989). Laboratory seismic measurements have shown that preferred orientation of anisotropic minerals (in particular phyllosilicates), may have a significant effect on seismic rock properties (e.g. Fountain et al., 1984; Jones ar.- Nur, 1984). The gently dipping reflections observed across geological

\footnotetext{
'Present address: Laboratoire pétrophysique et téctonique, Université Paul Sabatior, 3214090 Toulouse, France.

2Present address: IFP, BP 311, 92506 Rueil Malmaison, France.
}

structures such as the Brevard mylonite zone (Christensen and Szymanski, 1988 ) and the Kettle river mylonite zone (McDonough and Fountain, 1988) have been directly related to a large volume of oriented biotite minerals in ductile shear zones. Recently, Kern and Wenk (1990) have shown that, at constant bulk composition, seismic anisotropy in mylonites increases significantly with the amount of strain, i.e. with the degree of preferred Lattice Orientation (LPO) of phyllosilicates.

The aim of this study is to understand better the seismic response of a middle crust ductile shear zone. Different but complementary methods have been used for determinations of seismic properties of rocks: laboratory velocity mcasurements and velocity calculation based on petrofabric data.

The samples were collected from a geological structure exposed in the Saint Barthélémy Massif (Northern Pyrénées) representing a middle crustal section transected by a thick ductile shear zone. Its structure, composition and geometry was already well constrained by previous studies (Passchier, 1982; Saint Blanquat, 1989).

We have chosen five samples representing the main lithological units for the laboratory measurements and for two of these samples the seismic velocities have been calculated from the elastic constants of the constituent minerals and their LPO. Using a combination of experimentally and petrofabric-derived (cross-checked) rock elastic constants, we have modelled the seismic response of this exposed structure. The synthetic seismograms are the result of a calculation taking into account the 21 elastic constants characterizing the elastic properties of each unit.

\section{GEOLOGICAL SETTING}

\section{Lithology of the Saint Barthélemy Massif}

The Saint Bathélémy Massif (Passchier, 1982; Saint Blanquat, 1989) is located in the North Pyrenean Zone (Fig. la). It is scparated from the Variscan Axial Zone by a major crustal structure, the North Pyrenean Fault. The crustal section consists of the following bottom-to-top sequence (Fig. 1b):

(i) a paragneissic formation (2 km thick) containing small lenses of marble and amphibolite. The gneisses have been metamorphosed under LP-HT granulite facies conditions $\left(750 \pm 50^{\circ} \mathrm{C}\right.$ and $500 \pm 50$ $\mathrm{MPa}$ ) at late Variscan time (c. 300 $\mathrm{Ma}$, Delaperrière, pers. comm.). The main penetrative deformation of this basement is interpreted as 


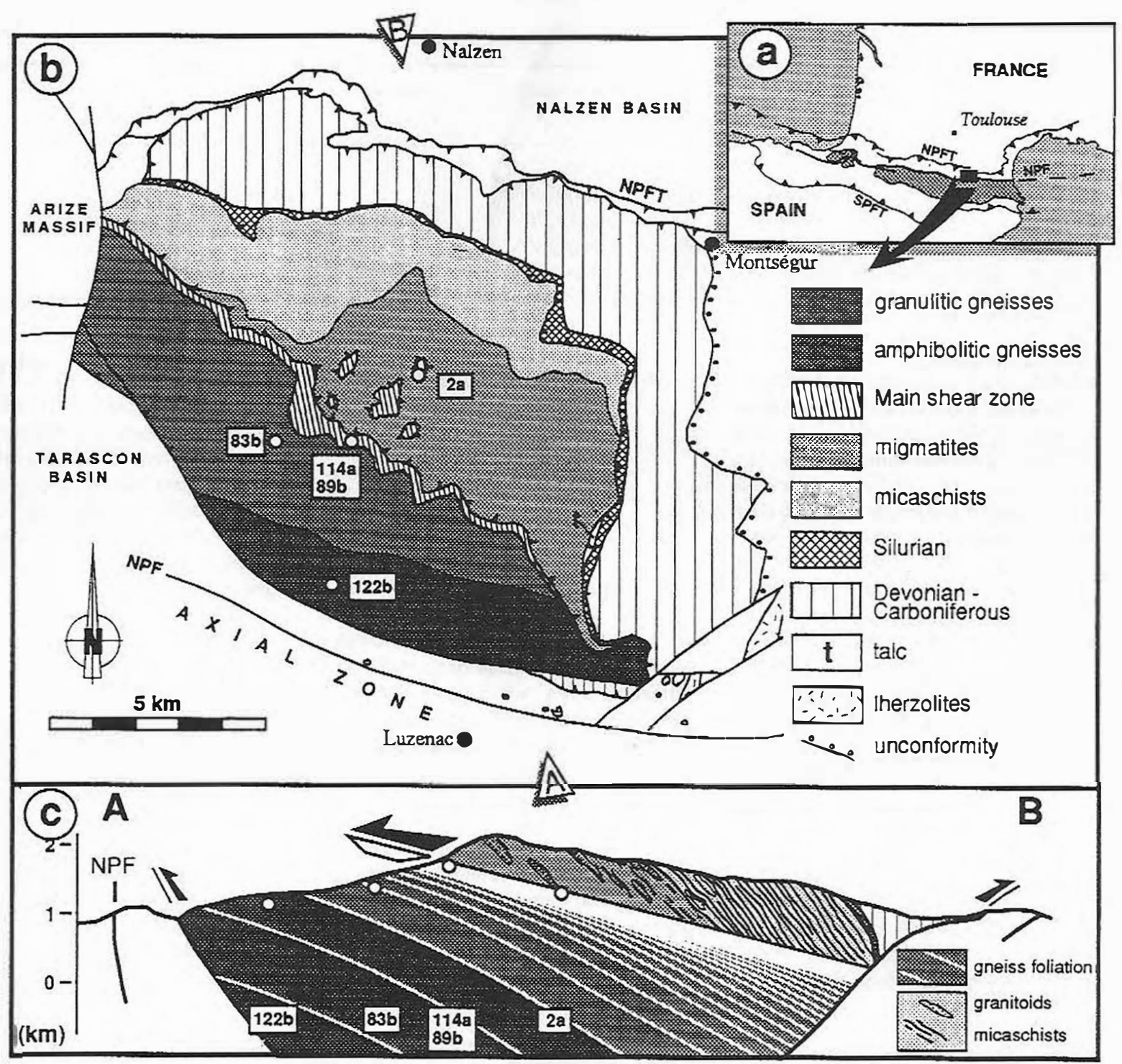

Fig. 1. (a) Location mapof the Saint Barthélémy (NPF: North Pyrenean Fault, NPTF: North Pyrenean Frontal Thrust, SPTF: South Pyrenean Frontal Thrust). (b) Schematic geological map of the massif, withsample locations (from Saint Blanquat, 1989). (c) Schematic cross section (the sample locations are projected onto the cross section).

having resulted from a progressive extensional event which started with granulitic metamorphism (Saint Blanquat, 1990).

(ii) a low angle ductile shear zone, 50-200 $\mathrm{m}$ thick, was initiated during the latest stages of the ductile deformation $\left(T \approx 450^{\circ} \mathrm{C}\right)$. It is composed of several anastomosing quartzo-feldspathic mylonites and mylonitized carbonate layers enveloped by a 1-5 $\mathrm{m}$ thick ultramylonite band. (iii) migmatites and micaschists (2 km thick) derived from lower Paleozoic series and intruded by granodioritic and leucogranitic sills.

(iv) an Upper Paleozuic series (shales and carbonates).

\section{Structure of the massif}

The foliation, both in the hanging wall (migmatites and micaschists) and in the footwall (granulitic and amphibolitic gneisses) of the ductile shear zone, is oriented $\mathrm{N} 10030^{\circ} \mathrm{N}$. A pronounced $\mathrm{N}-\mathrm{S}$ trending stretching lineation is developed in the shear zone and in the lower unit. The ductile shear zone (Fig. 1c) crosscuts the foliation in the bordering rocks at a small angle $\left(15^{\circ}\right)$. The strain increases markedly from the granulites to the ultramylonites. The overlying migmatites are undeformed. The total outcropping thickness of the ductile deformed zone (including gneisses) is about $2 \mathrm{~km}$. 
Table 1. Modal composition and density of the five selected samples

\begin{tabular}{llll}
\hline Sample & Rocktype & $\begin{array}{l}\text { Density } \\
\left(\mathrm{gcm}^{-3}\right)\end{array}$ & Modal analysis \\
\hline SB2a & Phyllonite & 2.83 & $100 \%$ Phyllosilicates \\
SB89b & Biotite rich ultramylonite & 2.79 & $45 \%$ Biotite, 25\% feldspars, 30\% quartz \\
SB114A & Ultramylonitic quartzite & 2.58 & $100 \%$ Quartz \\
SB83 & Amphibolitic gneiss & 2.65 & $35 \%$ Quartz, 15\% biot., 28\% micr., 18\% plag., 2\% sill, 2\% garnet \\
Sb122b & Acid granulite & 2.93 & $45 \%$ Quartz, 22\% felds., 15\% garnet, 8\% biot., 5\% sill, 5\% opx
\end{tabular}

\section{Rock samples}

115 samples were collected from two N$\mathrm{S}$ cross sections transecting the whole massif. Bulk densities were measured and lie within a narrow range of 2.6$2.8 \mathrm{~g} \mathrm{~cm}^{-3}$ indicating a relatively homogeneous, silica rich crustal section. The modal compositions of 40 of the samples were measured by an image analysis technique (Allard and Sutin, 1988). Based on the modal composition and the density measurements we have selected 5 representative samples, 3 from the shear zone (SB2a, SB89b, $\mathrm{SB} 114 \mathrm{a})$ and 2 from the lower unit (SB83, SB122b). The upper unit composed of migmatites, leucogranites and micaschists, has been considered, at a first approximation, to be isotropic duc to the extreme variability of lithologies and structures. Localities of these samples are indicatcd in the schematic geological map (Fig. 1b) and projected on a cross section plane (Fig. 1c). The sample modal compositions and densities are listed in Table 1.

\section{LABORATORY SEISMIC MEASUREMENTS}

\section{Method}

The velocity measurements at PT conditions were carried out in a cubic pressure apparatus at the Mineralogisch-Petrographisches Institut, Kiel (Germany) using the pulse-transmission technique. The method allows simultaneous measurements of $\mathrm{P}$ and Swave velocities in the three structural directions ( $X, Y$ and $Z$ ) of the cubeshaped specimens (Kern, 1982). Velocities were generally measured as a function of pressure (up to $600 \mathrm{MPa}$ ) and as a function of tempcrature (up to $600^{\circ} \mathrm{C}$ ) at a constant confining pressure of $600 \mathrm{MPa}$. For the determination of acoustic birefringence we used two sets of shear wave transducers with perpendicular polarization directions. S-waves were polarized in the $X Y, X Z$, and $Y Z$ planes. Assuming the fastest and the slowest velocities were generally measured parallel and normal to the foliation plane respectively, we determined the velocity anisutropy. The velocities of the two perpendicularly polarized shear waves propagating in the $X, Y$ and $Z$ directions allow in addition the calculation of acoustic birefringence. In the following text, $V_{\text {sij }}$ represents the velocity of a shear wave propagating in the ii plane, in the $j$ direction.

\section{P-wave measurements}

At low pressure conditions, average values increase rapidly with increasing pressure (Fig. 2), reflecting the closure of microcracks. Above $200 \mathrm{MTa}$ the curves become linear and represent the intrinsic elastic properties of the
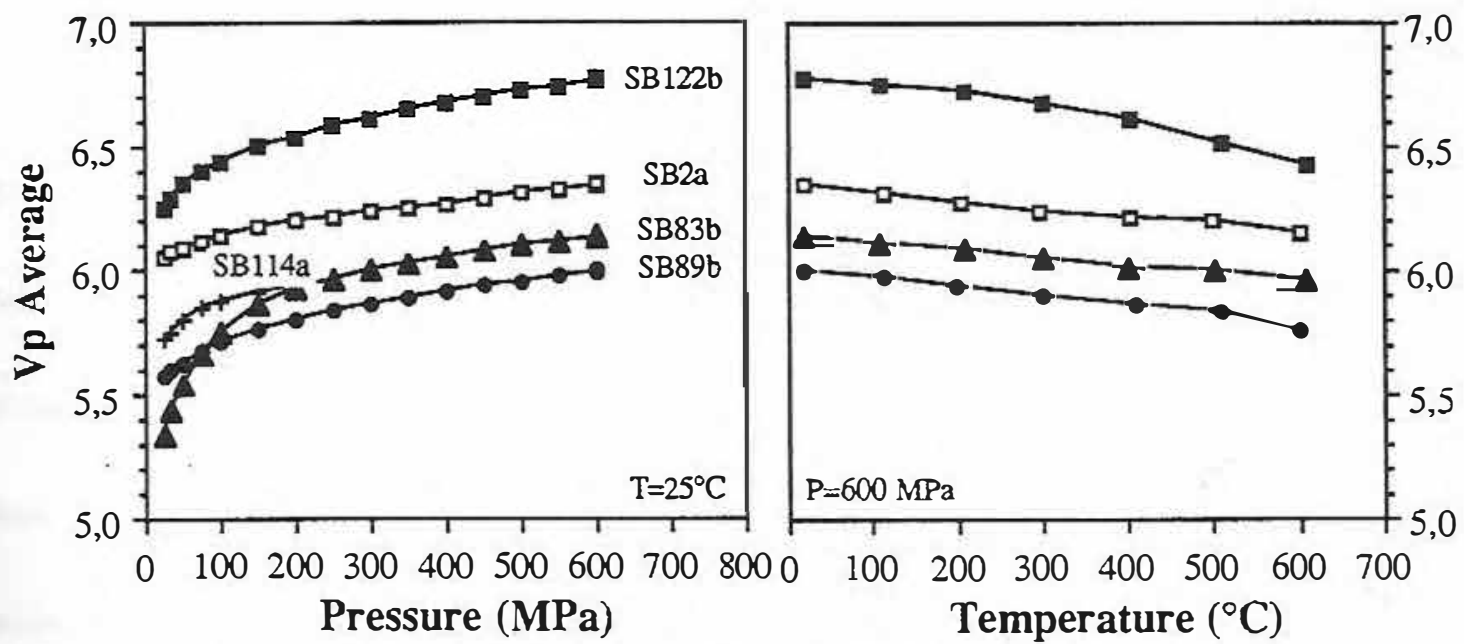

Fig. 2. Average measured $P$-wave velocities from the three structural directions of the five samples as a function of pressure at room temperature (left) and as a function of temperature at $600 \mathrm{MPa}$ confining pressure. The sample SB114a has been measured only up to $200 \mathrm{MPa}$ and is absent on the right-hand diagram. 
samples. The $\mathrm{P}$-wave velocities are not strongly influenced by the pressure increase above $200 \mathrm{MPa}$. For the phyllonite SB2a, for example, a pressure increase of $400 \mathrm{MPa}$ generates a $V_{\mathrm{p}}$ increase of about $0.15 \mathrm{~km} \mathrm{~s}^{-1}$. At 600 $\mathrm{MPa}$ a temperature increase results in a slight linear decrease of velocities. The derivatives of seismic velocities (Table 2) refer to the (quasi) linear slopes of the velocity-pressure and velocity-temperature relation, respectively between 200 $600 \mathrm{MPa}$ and $20-500^{\circ} \mathrm{C}$. The $600 \mathrm{MPa}$ (room temperature) $\mathrm{P}$-wave velocities are in a range of 5.8 and $6.8 \mathrm{~km} \mathrm{~s}^{-1}$, which was found to be typical for acidic rocks of low (phyllonite, mylonite) and high (granulite) metamorphic grade (Kern and Schenk, 1988; Kern and Wenk, 1990).

The studied samples exhibit significant velocity anisotropy. Slowest velocities were generally measured normal to the foliation plane, i.e. parallel to $\mathrm{Z}$ (Table 2). Anisotropies (A\% $=100$ $\left.\left(V_{\max }-V_{\min }\right) / V_{\max }\right)$ vary between $2 \%$ (gneiss SB 83b) and 16\% (phyllonite $\mathrm{SB2a}$ ) at $200 \mathrm{MPa}$. At and above this pressure, where most of the cracks are closed, anisotropy is mainly caused by crystallographic and shape-preferred orientation of minerals (texture). In the very low pressure range, however, oriented microcracks make a major contribution to velocity anisotropy producing the highest anisotropy values. The present results also confirm earlier observations (Barruol, 1988; Mainprice and Nicolas, 1989) that anisotropy decreases with the number of mineral species in the rocks (Table 2), and is most pronounced in phyllosilicate rich rocks. The phyllonite SB2a illustrates this phenomenon well: $\mathrm{P}$-wave velocity within the foliation plane is very homogeneous and fast, whereas the slowest is normal to the foliation (Fig. 3 bottom). It displays a strongly transverse isotropy characteristic of textured biotite-rich rocks (see also Kern, 1990). It is important to recognize that apart from the $\alpha-\beta$ quartz transition, the texture related anisotropy is almost pressure and temperature independent (Kern, 1990).

The quartzite mylonite SB114a displays well the influence of $\alpha-\beta$ quartz transition on anisotropy. At room temperature, the fast $V_{p}$ velocity is parallel to the $Y$ structural direction and the slow velocity is parallel to the $X$ direction (Fig. 3 top). With increasing pressure, the anisotropy remains almost constant (about 10\%). At $200 \mathrm{MPa}$, an increase in temperature up to $630^{\circ} \mathrm{C}$ reveals an important decrease of $V_{p}$ of almost I $\mathrm{km} \mathrm{s}^{-1}$. Simultaneously, the properties change from strongly anisotropic $(10 \%)$ to nearly isotropic (2\%). Above the transition, $V_{\mathrm{p}}$ increases markedly by about $2 \mathrm{~km} \mathrm{~s}^{-1}$ and exhibits only a small directional dependence in the $\beta$-field (see also Mainprice and Casey, 1990).

\section{S-wave measurements}

Pressure and temperature influence on S-wave velocities are qualitatively very similar to $\mathrm{P}$-waves. The difference $\Delta V_{s}=V_{s} 0-V_{s} 90$ (see Table 2 for definitions) for each structural direction characterizes the shear wave birefringence. Typical values range fom 0 to $0.3 \mathrm{~km} \mathrm{~s}^{-1}$. Pressure and temperature derivatives determined from the linear slope of the seismic velocities (Table 2) yield values in agreement with previous determinations (Christensen, 1979; Kern and Richter, 1981).

In elastically anisotropic rocks, shearwave velocities strongly depend on their polarization directions. Pronounced acoustic birefringences (shear

Table 2. Laboratory velocity measurements summary, for the three structural directions, for the P-waves (velocities, anisotropies, pressure and temperature derivatives) and for the S-waves (velocities, birefringence, pressure and temperature derivatives). The temperature derivatives have not been calculated for sample SB114a due to the non linearity of the curves.

\begin{tabular}{|c|c|c|c|c|c|c|c|c|c|c|}
\hline \multicolumn{2}{|l|}{ Sample } & \multicolumn{2}{|l|}{ P-waves } & \multicolumn{3}{|l|}{ S-waves } & \multicolumn{4}{|c|}{ Derivatives } \\
\hline & & \multirow[t]{2}{*}{$\begin{array}{l}V_{\mathrm{p}} \\
\left(\mathrm{kms}^{-1}\right)\end{array}$} & \multirow[t]{2}{*}{$\begin{array}{l}A V_{p} \\
\%\end{array}$} & \multirow[t]{2}{*}{$\begin{array}{l}V_{s 0} \\
\left(\mathrm{~km} \mathrm{~s}^{-1}\right)\end{array}$} & \multirow[t]{2}{*}{$\begin{array}{l}V_{s y 0} \\
\left(\mathrm{kms}^{-1}\right)\end{array}$} & \multirow[t]{2}{*}{$\begin{array}{l}\Delta V S \\
\left(\mathrm{kms}^{-1}\right)\end{array}$} & \multicolumn{2}{|c|}{$\begin{array}{l}d V / d P \\
\left(\times 10^{-4} \mathrm{~km} \mathrm{~s}^{-1} \mathrm{MPa}^{-1}\right)\end{array}$} & \multicolumn{2}{|c|}{$\begin{array}{l}-d V / d T^{\circ} \\
\left(\times 10^{-4} \mathrm{kms}^{-1}{ }^{\circ} \mathrm{C}^{-1}\right)\end{array}$} \\
\hline & & & & & & & P-waves & S-waves & P-waves & S-waves \\
\hline \multirow[t]{3}{*}{ SB2a } & $1 / X$ & 6.60 & & $y \times 4.06$ & $z \times 3.00$ & 1.06 & & & & \\
\hline & $I / Y$ & 6.50 & & xy 4.12 & zy 3.03 & 1.09 & & & & \\
\hline & $\| \mathrm{Z}$ & 5.49 & 16.8 & $x z 3.01$ & yz 3.00 & 0.01 & 3.33 & 1.33 & 2.83 & 1.50 \\
\hline \multirow[t]{3}{*}{ SB89b } & $\| X$ & 6.01 & & $y \times 3.76$ & $\mathrm{z} \times 3.38$ & 0.38 & & & & \\
\hline & $\mathbb{I} Y$ & 5.97 & & xy 3.81 & zy 3.37 & 0.44 & & & & \\
\hline & $\| Z$ & 5.42 & 9.8 & $x z 3.24$ & $y z 3.27$ & 0.03 & 5.33 & 1.16 & 3.67 & 1.33 \\
\hline \multirow[t]{3}{*}{ SB114a } & $/ / X$ & 5.63 & & $y \times 3.83$ & $z \times 4.15$ & 0.32 & & & & \\
\hline & $/ / Y$ & 6.24 & & xy 3.90 & zy 4.12 & 0.22 & & & & \\
\hline & $/ / Z$ & 5.95 & 9.7 & $x z 4.13$ & yz 4.15 & 0.02 & 5.50 & 3.5 & $?$ & $?$ \\
\hline \multirow[t]{3}{*}{ SB83b } & $/ / X$ & 5.97 & & $y \times 3.57$ & $z \times 3.57$ & 0.00 & & & & \\
\hline & $I / Y$ & 5.93 & & xy 3.63 & zy 3.49 & 0.14 & & & & \\
\hline & $\| Z$ & 5.87 & 1.6 & $x z 3.49$ & yz 3.58 & 0.09 & 3.33 & 1.33 & 2.60 & 0.50 \\
\hline \multirow[t]{3}{*}{ SB122b } & $\| X$ & 6.82 & & $y \times 3.89$ & $z \times 3.86$ & 0.03 & & & & \\
\hline & $I N$ & 6.67 & & xy 3.71 & zy 3.60 & 0.11 & & & & \\
\hline & $\| Z$ & 6.14 & 10.1 & $x z 3.67$ & yz 3.67 & 0.00 & 5.50 & 1.33 & $\# 4.42$ & \#1.71 \\
\hline
\end{tabular}




\section{Sample SB114a}
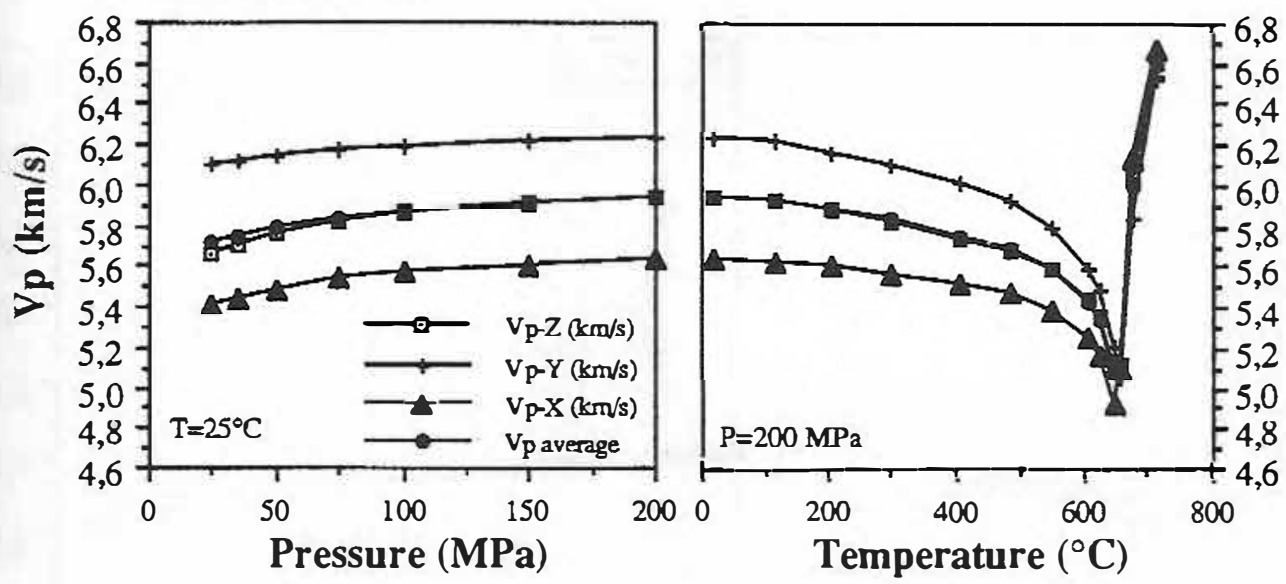

Sample SB2a
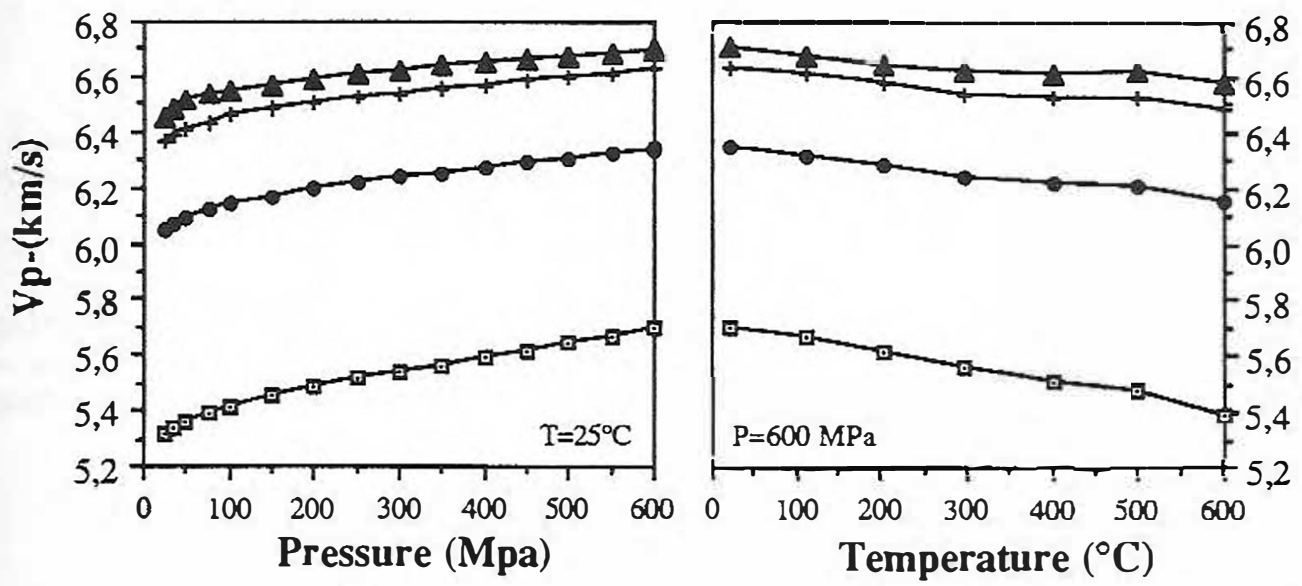

Fig. 3. Laboratory measurements of $\mathrm{V}_{p}$ for the quartzite SBI 14a (top) and of the phyllonite SB2a (bottom), with increasing pressure (left) and rith increasing temperature (right). The velocities measured in the three structural directions are plotted. The caption is the same for the two samples.

wave splitting) were observed in the phyllonite and mylonite samples (SB2a, $\mathrm{SB} 89 \mathrm{~b}$ and SB114a). Birefringence as high as $1 \mathrm{~km} \mathrm{~s}^{-1}$ was observed within ine foliation plane (Table 2). Shear wave splitting is closely related to the strucrugl framework. The fast and slow shear-waves are respectively polarized carallel and normal to the foliation. In ine phyllonite SB2a, for example (Fig. 4) $V$ and $V_{\text {syx }}$ are the fastest S-waves jecause both their propagating direcjons and their polarization planes are contained in the $X Y$ plane. In such bioite rich rocks, thereforc, S-waves propzgating either normal to the foliation or Dolarized perpendicularly to it have low relocities.

\section{D seismic properties extrapolated from direct measurements}

The technique we used to model the anisotropic seismic properties of our geological object requires the 21 elastic constants for each element of the model, that means we need to extrapolate the velocities $\left(V_{\mathrm{p}}, V_{\mathrm{s}}\right)$ measured in the three mutually perpendicular directions $(X, Y, Z)$ to an arbitrary direction. To determine the shape and the axial ratio of the velocity ellipsoid, the Flinn diagram has been used. The ratio $V_{p x} J V_{p y}$ versus $V_{p y} / V_{p z}$ is plotted for each sample (Fig. 5). In an ideal transverse isotropic case, the point would be placed on the $K=0$ or $K=\propto$ axes (cor- responding to pancake-like and cigarlike ellipsoids, respectively). The points representing the three studied samples (SB2a, SB89b and SB122b) fall close to the line $K=0(K=0.064,0.038$ and 0.273 , respectively). The $K$ values are defined as $\mathrm{K}=\left(\left(V_{p x} / V_{p y}\right)-1\right) /\left(\left(V_{p y} /\right.\right.$ $\left.\left.V_{p z}\right)-1\right)$. The velocity ellipsoids determined for these three samples are close to the transversely isotropic case $(K=0)$, especially for the two mylonites (SB2a and SB89b). Their elastic constants (Fig. 9) can now be determined for these three samples assuming the symmetry to be transverse isotropic, using the method described in Christensen and Crosson (1968) and in Seront et al. (1992). The low $V_{\mathrm{p}}$ aniso- 


\section{Sample SB2A phyllonite}
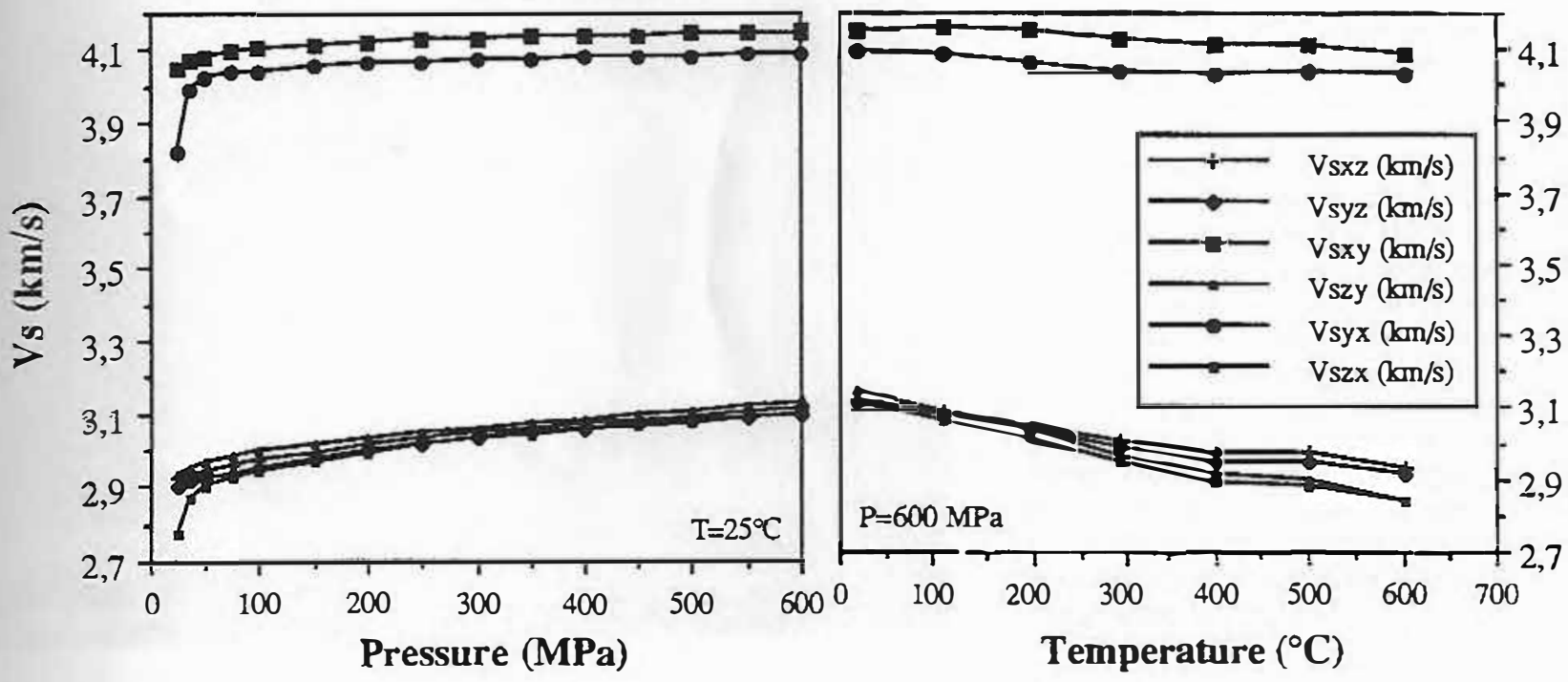

Fig. 4. S-wave measurements for phyllonite SB2a along the six polarization planes (cf Table 2 for the notion of $V_{s}$ ) with increasing pressure (left) and with increasing temperature (right). $\mathrm{V}_{\text {sij }}$ represent a shear wave velocity within the ij plane and in the $\mathrm{j}$ direction.

tropy $(1.4 \%)$ of the gneiss SB83 explains why the shape of its velocity ellipsoid is not significant. The quartzite SB114a is

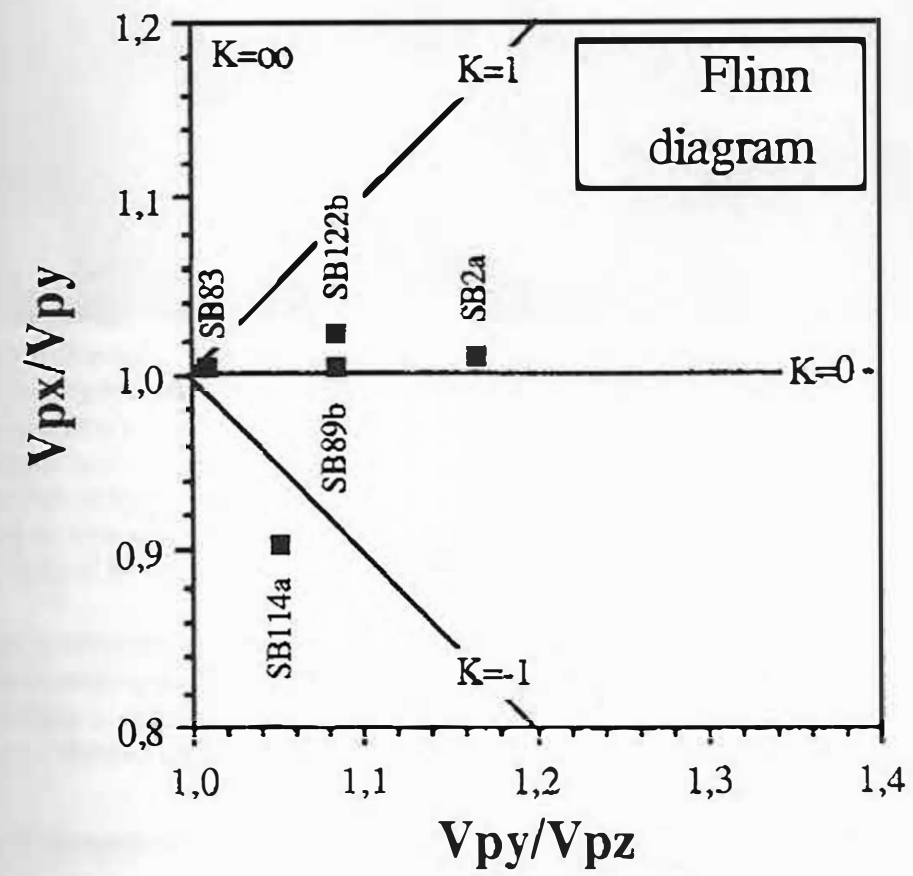

Fig. 5. Flinn representation of the anisotropy of the laboratory measured $P$-wave velocities for ihe five samples. (see text for explanations). close to the line $K=-1$, and cannot be described as a transverse isotropic case.

\section{VELOCITY CALCULATIONS FROM PETROFABRIC DATA}

\section{Determination of Lattice Preferred Orientation (texture)}

Two specimens (SB114a and SB83b) were selected for the velocity calculations. The microstructures of the specimens are illustrated in Fig. 6.

Pole figures of quartz in sample SB114a were measured by neutron diffraction goniometry. A solid cylinder (10 $\mathrm{mm}$ diameter and $20 \mathrm{~mm}$ length) of this monomineralic and fine-grained rock $(10 \mu \mathrm{m})$ provides a good statistical representation of the crystallographic texture. LPO of mincral phases of the gneiss SB83 were obtained either using the universal stage on an optical microscope (biotite) or by scanning electron microscopy (SEM) using the selected area electron channelling pattern (SAECP) method (Quartz, Plagioclase and K-feldspar) (Lloyd et al., 1981). SEM provides a powerful tool for measuring partial textures in polyphase material, in particular for minerals optically difficult to measure (plagioclase) or from which it is impossible to obtain complete crystallographic information (quartz). The SEM determination of the complete crystallographic orientation 

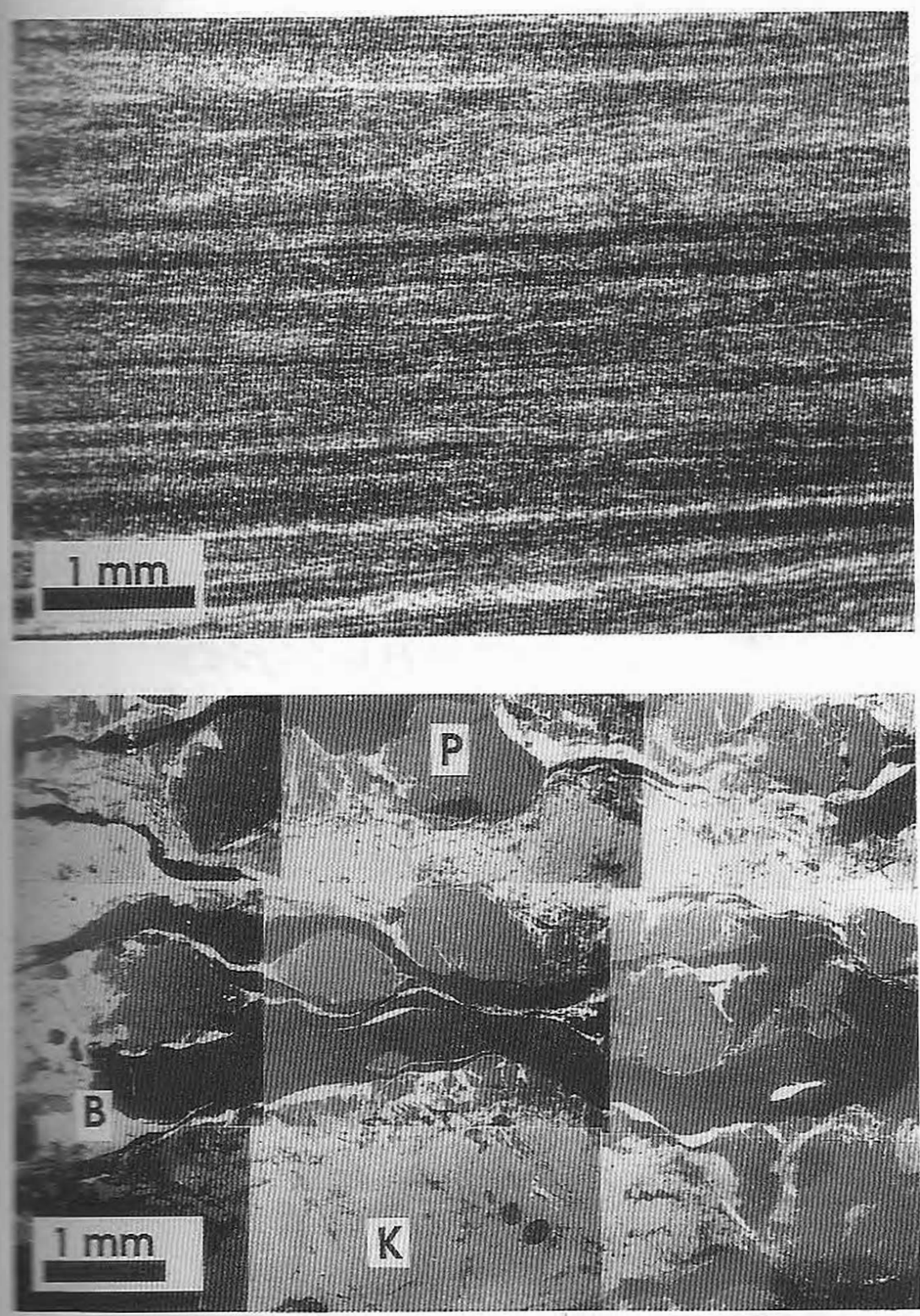

E. Microphotographs of the monomineralic quartzite, optical microscopy, crossed nicols IF) and of the polymineralic gneiss, SEM backscattered image (bottom), both in the XZ Tu=. The quartzite is very fine grained $(10 \mu \mathrm{m})$ and strongly textured. In the gneiss, quartz cosucture is typical of plastic deformation. Grains are ribbon shaped and often bent strain free feldspar porphyroclasts. Despite the intense plastic deformation, quartz $=$ display no sign of dynamic recrystallization. $Q=$ quartz, $K=K$-feldspar,

$=$ =ixgioclase and $B=$ biotite.

$z=7$ grain is obtained by indexing the cried channelling pattern (Lloyd et

ig97) using a computer program sicidt and Olesen, 1989).

\section{sedure of velocity calculation}

ZE Ekalation of the three dimensional ation of elastic seismic velocities these calculations. The procedure of calculation is described in detail by Crosson and Lin (1971) and Peselnick (1974). Computations were performed using an interactive program (Mainprice, 1990).

The elastic constants of $\alpha$-quartz single crystal (trigonal) used were those reported by McSkimin et al. (1965), and for biotite (monoclinic, pseudohexagonal) we used those recently reported by Vaughan and Guggenheim (1986) for muscovite. The seismic properties of muscovite are very close to those determined by biotite (considered as hexagonal) by Aleksandrov and Ryzhova (1961). The data for feldspars used in these calculations were determined by Aleksandrov et al. (1974) for microcline and plagioclase (An29\%).

\section{Lattice Preferred Orientation (LPO) and calculated velocity distributions}

The lattice preferred orientations of the major minerals constituting sample SB114a (quartzite) and SB83 (gneiss) are documented in Figs 7 and 8, respectively.

In the quartzite SB114a, (Fig. 7 left) the maximum of quartz a-axes is close to the lineation and the $c$-axes are grouped in two maxima between the $Y$ and $Z$ structural axis. The m-axes pole figure (not shown) is very similar to the a-axes pole figure and the $\mathbf{r}+\mathbf{z}$ measured pole figure (not shown) exhibits two maxima between the $Y$ and $X$ directions, in the foliation plane. The fabric does not exhibit any clear obliquity with respect to the structural frame $(X Y Z)$. These pole figures could arise from intracrystalline slip mainly on the rhombohedral $\mathbf{r}$ crystallographic plane, in the [a] directions. The pole figures of the polymineralic gneiss SB83 are shown in Fig. 8 (left).

The Quartz c-axes form a broad girdle in the $Y Z$ plane, with a maximum close to the $Y$ axis. The corresponding a-axes scatter around $Y$ in the projection plane. This fabric is typical of amphibolite facies metamorphic conditions (Mainprice and Casey, 1990; Schmid and Casey, 1986). The Biotite c-axes (close to the pole of the main cleavage of the crystal, the (001) plane) form a strong maximum normal to the foliation, with a larger angular spread toward $X$ than toward $Y$, mainly due to deflection of the foliation around the feldspars por- 


\section{Sample SB114a - quartzite \\ Pole figures \\ seismic properties}

Measured Pole figures

a axis

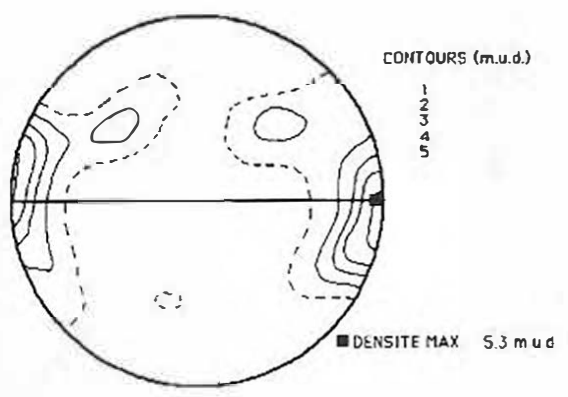

Calculated Pole figures $c$ axis

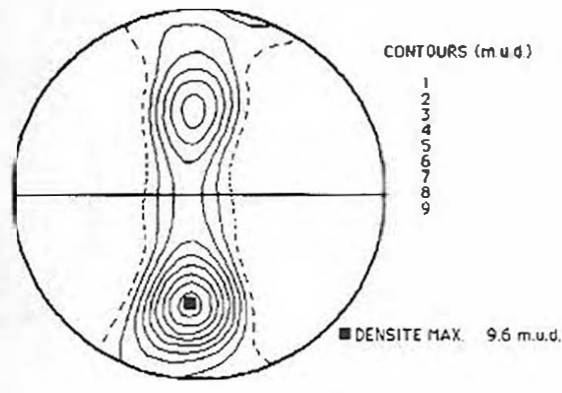

\author{
Calculated \\ $\mathrm{P}$ waves distribution
}

$25^{\circ} \mathrm{C}$

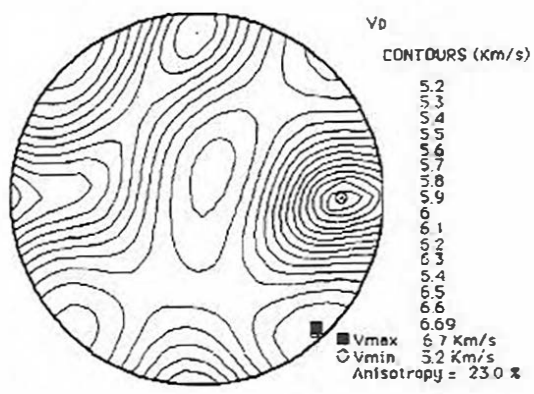

Fastest shear wave polarization planes

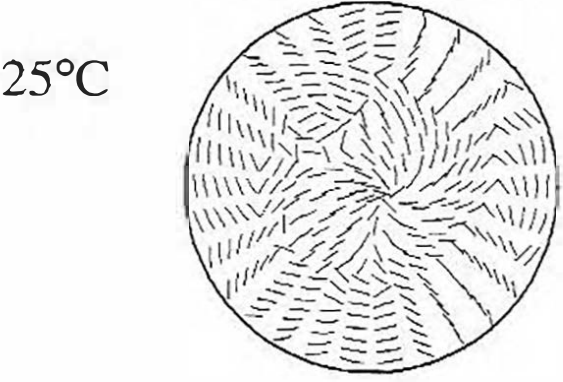

Fig. 7. Quartzite SB114a: $a$ and c-axes pole figures (left) and some calculated seismic properties from these petrofabrics ( $P$-wave velocity distribution at $25^{\circ} \mathrm{C}$ and the orientation of the fastest S-wave polarization planes). The equal area projections are in the lower hemisphere, the foliation is EW, normal to the paper and the lineation EW.

phyroclasts. For seismic properties computation, the a-axis orientation of each biotite grain, has been generated randomly in a plane normal to the pole of the cleavage $\left(c^{*}\right)$, assuming biotite to be transverse isotropic. Pole figures of $\mathrm{K}$-feldspar and plagioclase a-axes and of the $+(001)$ planes do not exhibit any preferred orientation. It should bc mentioned, however, that the small number of measured grains may not give a statistical representation of the zggregate.

Figure 7 (right) presents the calculated velocity surfaces of the monomineralic quartzite SB114a. The minimum Pwave velocity $\left(V_{\text {pmin }}\right)$ is close to $X$ and correlates to the a-axes maximum. The a-axis represents the slowest velocity in the quartz single crystal. $V_{\text {pinin }}$ parallel to $X$ is in good agrecment with experimental measurements (see Table 2). $V_{\text {pmax }}$ lies between the $X$ and $Z$ axis and is related to the $\mathbf{z}$ crystallographic axis (not shown) which represents the direction of the fastest P-wave in quartz single crystal. The corresponding shear wave properties $\left(V_{s}\right.$ and polarization planes) have been calculated and are shown in Figs 9 and 7, respectively. In an anisotropic aggregate shear waves split into two waves with different velocitics and polarization directions (Crampin, 1985). The two shear waves $V_{s} 1$ (fast) and $V_{s} 2$ (slow) are polarized in mutually perpendicular planes. In equal arca projection (Fig. 7), the shear wave polarization is indicated by a little arc segment of a great circlc. The arc marks the oricntation of the fastest shear wave (s1).

Considering the quartzite spccimen in its structural framework, it follows from Fig. 7 (orientation of the polarization planes) and of Fig. 9 (spatial distribution of $V_{s 1}$ and $V_{52}$ ) that significant shear wave splitting occurs for $S$-waves propagating parallel to the foliation plane. The fast shear waves (s1) cluse to the lincation are polarized normal to the foliation plane, and the corresponding slow shear wave (s2) parallel to it. This is in excellent accordance with the experimental results (sce Table 2). On the 


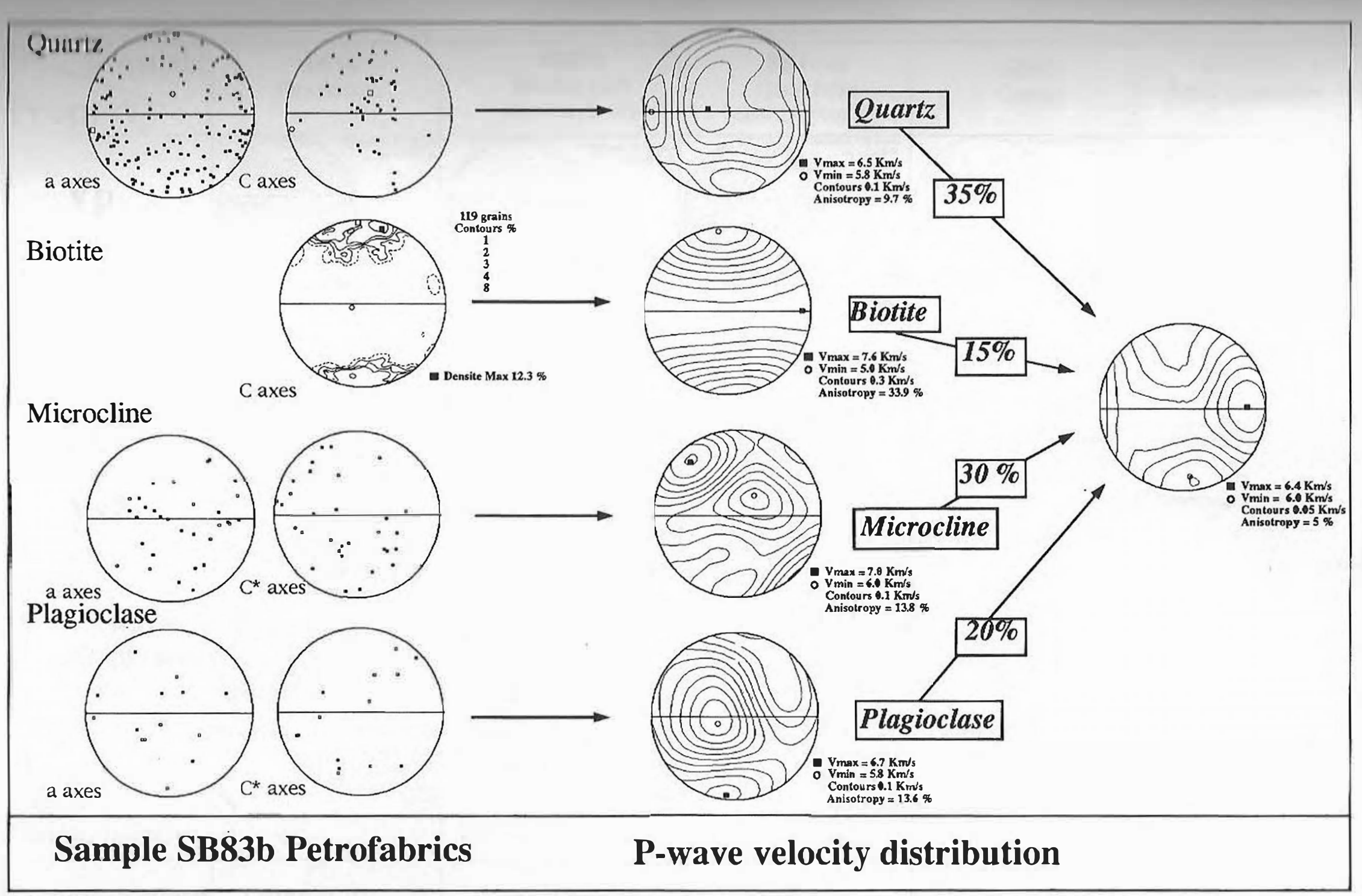

Fig. 8. Gneiss SB83b: Calculation of the P-wave velocity distribution of a complex aggregate from the knowledge of the preferred orientation of each mineral phase. On the left, preferred orientation of the a and c crystallographic axes of quartz, biotite, K-feldspar and plagioclase. In the middle part of the figure are shown the P-wave velocity distributions of each virtual single phased aggregates. The modal composition is used to calculate the $\mathrm{V}_{p}$ spatial distribution taking into account each mineral phase in its bulk proportion. The equal area projection characteristics are the same as in Fig. 7. 


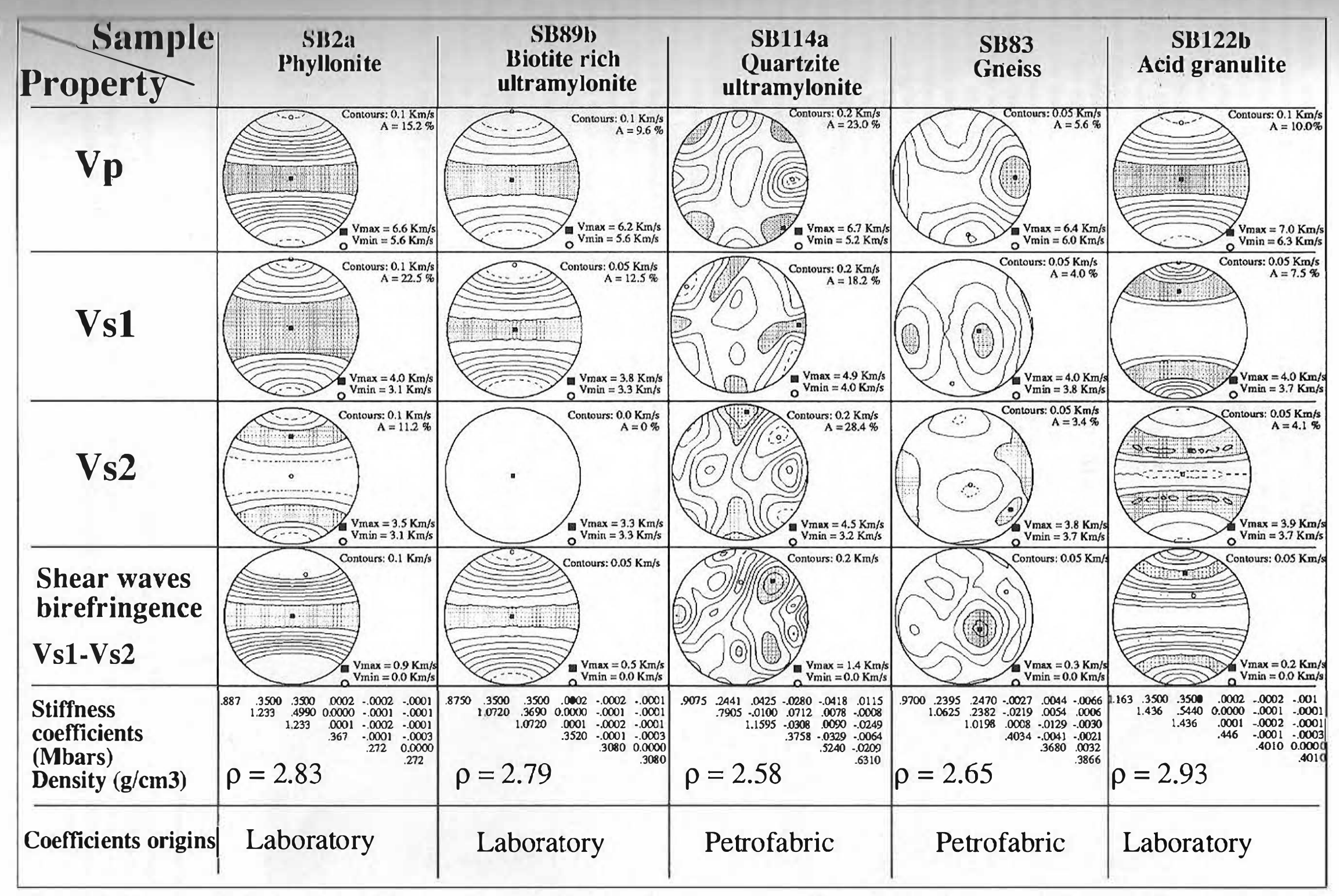

Fig. 9. Seismic properties of the five samples studied. Shown are the velocity distribution of the P-waves, of the two S-waves (for their significance see text), of the birefringence and the 21 elastic constants controlling the aggregate property (in Mbar). The velocities of the samples SB2a, SB89b and SB122b are laboratory derived. For the samples SB114a and SB83b the velocities are petrofabric derived. The equal area projection characteristics are the same as in Fig. 7. 
$=$ hand, returning the quartzite ple to its crustal setting assuming its sation is horizontal, and considering a sismic wave propagating upward -ically, the shear waves will split at $=$ lowest interface of the quartzite axyer and will propagate with different recoities. The fastest (s1) will propaDertically within the $X Z$ plane, i.e. Z a plane parallel to the lineation. The sonest (s2) will propagate vertically $I 0$, but in the $Y Z$ plane, i.e. in a plane cosmal to the lineation. In real seismic ccords, measurements of the delay me between the two shear wave arrials, the shear wave splitting and the ientations of their polarization ji-nes, allows one to extract structural cinematic information. The polarization zine of s1 may be a marker of the lineaion, and the magnitude of the shear vave splitting may indicate the comined values of anisotropy and the trickness of the layer.

The velocity distribution of the polymineralic gneiss SB83 (Fig. 8) is based on the partial textures and the colume percentages of the major minzals. The direction of the fastest $P$-wave is close to $X$ within the foliation plane and the calculated bulk velocity anisoIopy is found to be around $5.6 \%$. The relocity distribution in the composite s5regate is dominated by the biotite Ivistals, due to their strong preferred rientation and the pronounced veloc$\because$ anisotropy (33.9\%) of this mineral reccies.

In Fig. 10 comparison is made betreen measured and calculated P-wave Elocities in the three structural direczons of the gneiss and ultramylonitic ziatzite. The results obtained by the two methods compare fairly well. The maximum deviations are around $4 \%$. This small value could be explained by the shape preferred orientation of grains, not taken into account in these calculations. The calculated velocity anisotropies are generally higher than those measured experimentally.

\section{SEISMIC MODELLING}

The synthetic seismogram program (DRT4) uses a 3D ray tracing method. It generates seismic traces for three component receivers. The receivers and the source may be in any geometrical disposition, at the surface or at any depth. The geometric model is a parallelepiped divided in homogeneous or heterogeneous layers. Each layer is defined by its physical properties (the density and the 6 by 6 elastic stiffness $\left(C_{i j}\right)$ matrix) and by its three dimensional geometry, excepting discontinuities. The program may generate all types of seismic signatures (reflection, transmission or multiples) for $\mathrm{P}$ and $\mathrm{S}$ waves but they must be explicitly specified in the input parameters. The ray path in each layer is obtained calculating first the isotropic case and then calculating the pertubation due to three dimensional velocity distribution. The obtained seismic traces are not true amplitude.

Schematically, the algorithm used by DRT4 is the following: the first step is a scan to find the rays joining source and receivers. The second step is a ray tracing including amplitude computation along the selected rays which allows a modelling using the 'Gaussian Beams
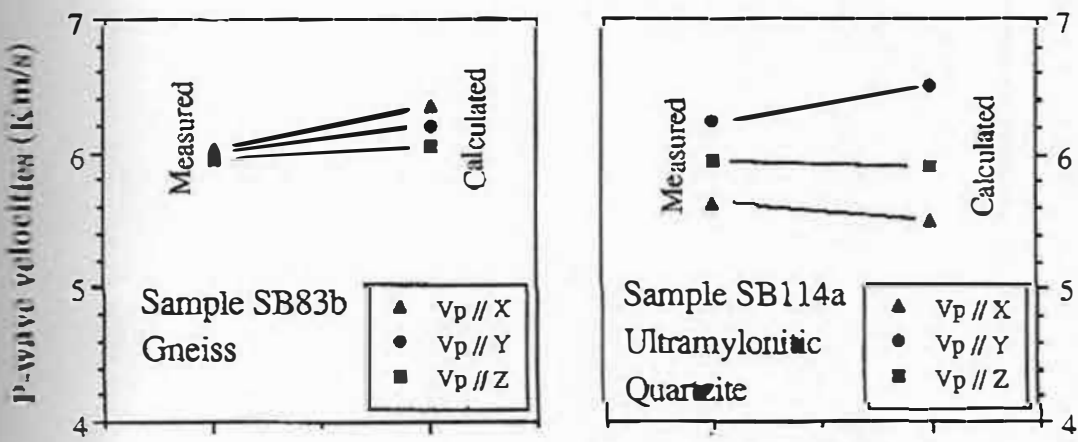

Fig. 10. Comparison of P-wave velocities measured (in laboratory) and calculated (from Ditofabrics) for the samples SB83 (left) and SB114a (right), and for the three structural Ërections.
Technique'. The last step is the computation of the seismic traces.

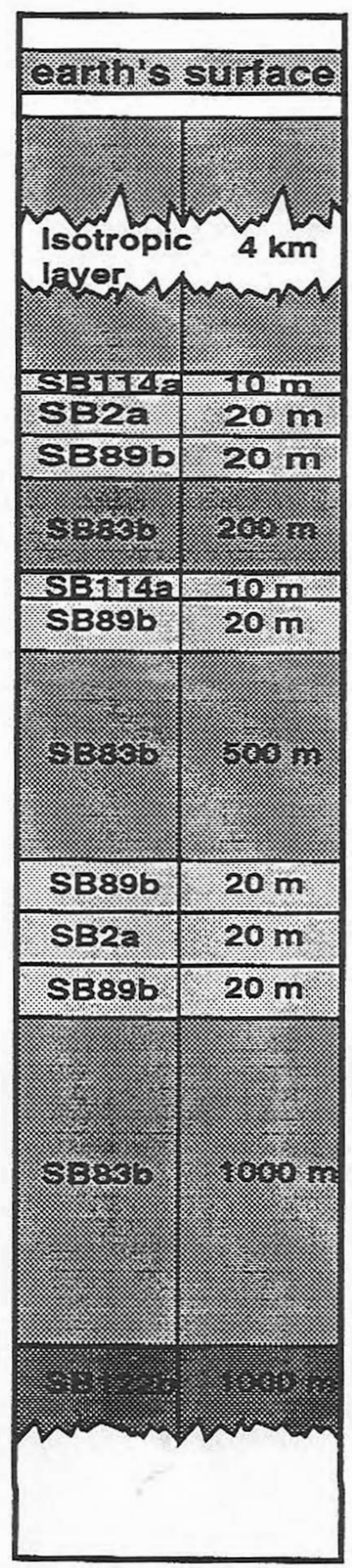

Fig. 11. 1D geological model, composed by a succession of the five samples studied. The relative thicknesses are not drawn to scale. The left column indicates the sample name and the thickness is in the right column. 


\section{Geometry of the model - seismic parameters}

We have considered the St Barthélémy section at the end of the period of extension, under upper crustal conditions (about $4 \mathrm{~km}$ depth), with the structures horizontal. The model was composed of 13 layers (Fig. 11). The anastomosing character of the shear zone is represented by three repeated sequences of mylonites separated by a layer of gneiss several hundred metres in thickness. Each mylonite layer was 10 or 20 metres thick. This very simple approach is clearly not a true 3D seismic modelling. Layers are indeed planes, horizontal and laterally homogeneous. Only the seismic velocities have three dimensional variations. The corresponding isotropic modelling using the average elastic parameters has not been carried out because the main interest of such a model is to study the first-order seismic signature it can generate rather than the influence of anisotropy.
The characteristics of the seismic line were as follows: the source was omnidirectional with a ricker centred at $30 \mathrm{~Hz}$ situated at one end of the seismic line on surface. 80 receivers were aligned in a parallel array every 100 metres. The rock layers were plane and horizontal. The calculated seismic signatures are $\mathrm{P}$ $\mathrm{P}$ and $\mathrm{P}-\mathrm{S}$ reflections on each interface.

\section{Results}

On seismic traces (Fig. 12) vertical movements display well the three $P$ wave reflections generated by the three shear zones, between 1.3 and $1.6 \mathrm{~s}$. The contact gneiss/granulites also generates a strong $\mathrm{P}$ reflection (at about $2 \mathrm{~s}$ ). The first $\mathrm{P}-\mathrm{S}$ reflections are also visible at about $1.7 \mathrm{~s}$ but have a smaller amplitude. On the radial movement traces, $P$-wave reflections become visible at about $1.5 \mathrm{~km}$ offset (at about $1.3 \mathrm{~s}$ ) and their small amplitudes increase with increasing offset whereas P-S reflections have a stronger amplitude and are visible even at small offsets $(0.5 \mathrm{~km}$ and $1.7 \mathrm{~s})$.

\section{CONCLUSIONS}

In this study, the seismic properties of a ductile shear zone have been studied. Whereas the rock types have been represented by a small number of samples (5), the results provide much information and show the usefulness of the methods.

The seismic properties have been determined using different but complementary methods. Each one has its own advantages: (i) Laboratory measurements give direct and accurate control of seismic properties, in an important range of geological conditions (pressures up to $600 \mathrm{MPa}$ and temperatures up to $600^{\circ} \mathrm{C}$ ). In addition to the classic $\mathrm{P}$-wave velocity measurement we have also measured the S-waves (velocities, polarization planes and bi-
0

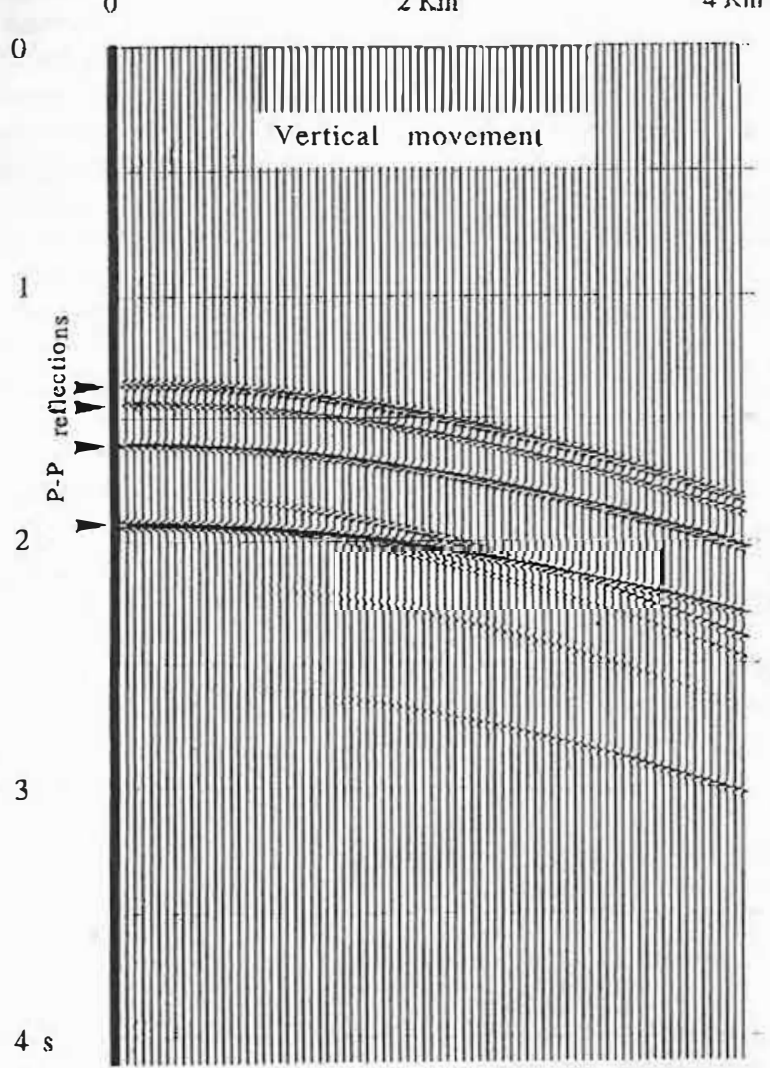

()

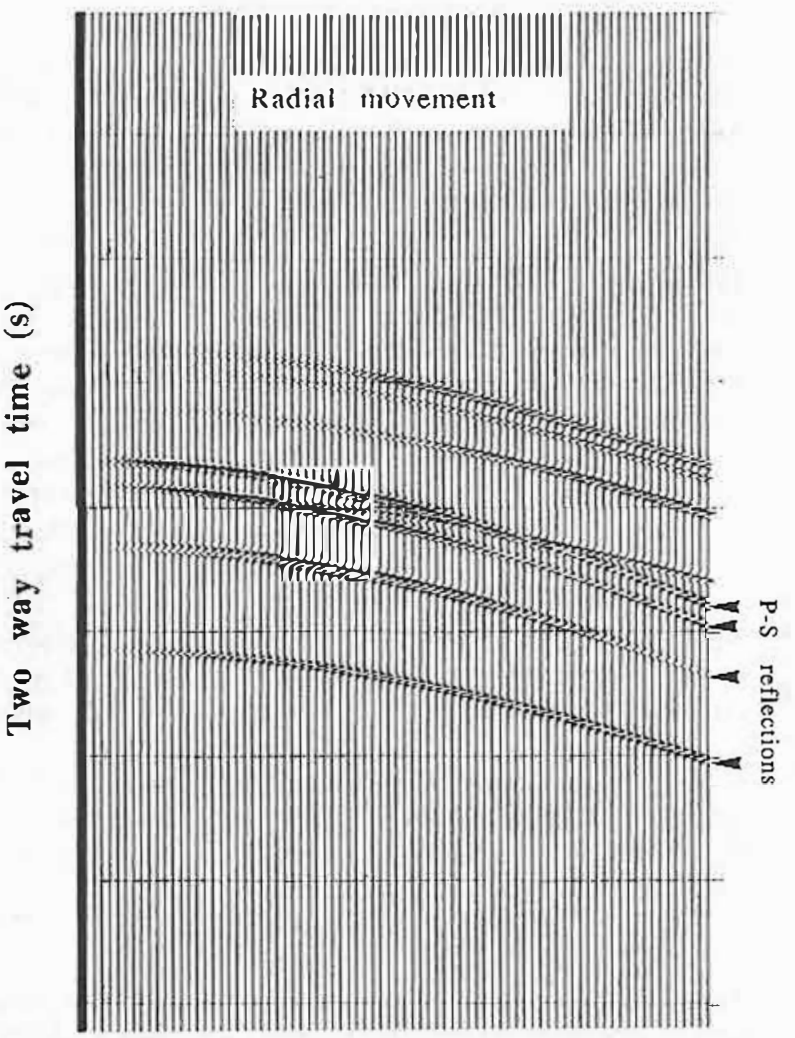

Fig. 12. Seismic traces corresponding to the model shown in Fig. 12. The vertical movements and the radial movement are displayed, respectively on the left and on the right. 
-efringence) which are an important seismic and kinematic diagnostic. (ii) The calculation of the elastic properties irom petrofabric data allows the determination of the true $3 \mathrm{D}$ variations of the complete seismic properties (characferized by the 21 elastic constants). An interesting approach, shown here, is to study the respective influence of each mineral phase on the seismic properties of the aggregate as a whole. The knowledge of petrofabrics has also a structural and kinematic interest.

Petrofabrics have been determined using different and complementary tools: (i) Optical microscopy allows the determination of LPO of simple mineral phases (orthorhombic crystal symmetry for example). (ii) Neutron diffraction goniometry gives a very good representative LPO of a single phased rock and (iii) SEM is a powerful tool for the study of complex aggregates of low symmetry mineral phases (trigonal, monoclinic or triclinic for example).

The results measured (in laboratory) and calculated (from petrofabrics) for the two samples on which the two methods have been applied (SB114A and SB83b), are in good agreement.

The seismic modelling shows that such a schematic representation of a geological structure may generate reflections looking like those commonly observed on seismic profiles.

Finally, the main potential value of 3D seismic anisotropy is the extraction of the kinematic information carried by shear waves. Real, three component seismic records of $\mathrm{S}$-wave polarization planes and of S-wave splitting may provide structural and kinematic information (Silver and Chan, 1988). This study has shown how one may determine the three dimensional shear wave properties (velocities, polarization planes, birefringence) of complex rocks. The 3D synthetic seismogram and the 3 component recording give us the opportunity to model the shear wave splitting.

\section{ACKNOWLEDGEMENTS}

This study has been supported by the Accompagnement ECORS $89 / 90$ program. Thanks to G. Lloyd for the useful help and advice for the SEM measurements undertaken at Leeds University (England), to E. Rutter and K.J. Sand- meier for their constructive comments, to the C.E.A. (Saclay) for the neutron diffraction measurements kindly undertaken by $\mathrm{T}$. Baudin, to the Compagnie Générale de Géophysique (Massy) for the program for 3D scismic modelling, to the Centre National Universitaire Sud de Calcul (Montpellier) for the computation time on the IBM 3090.

\section{REFERENCES}

Aleksandrov K.S., Alchikov U.V., Belikov B.P., Zaslavskii B.I. and Krupnyi A.I. (1974) Velocities of elastic waves in minerals at atmospheric pressure and increasing precision of elastic constants by means of EVM (in Russian), Izv. Acad. Sci. USSR, Geol. Ser., 10, 15-24.

Aleksandrov K.S. and Ryzhova T.V. (1961) The elastic properties of rock forming minerals, II: Layered silicates, Izv. Acad. Sci. USSR, Geophys. Phys. Solid Earth, 1165-1168.

Allard B. and Sotin C. (1988) Determination of mineral phase percentages in granular rocks by image analysis on a microcomputer, Computer \& Geosciences, 14, 261-269.

Barruol G. (1988) Anisotropies sismiques dans la croûte inférieure. Exemple de la section du Val Sesia dans la Zone d'Ivrée, D.E.A., Montpellier II, 122 pp.

Choukroune $P$. and Pyrénées ECORS Team (1989) The ECORS Pyrenean deep seismic profile reflection data and the overall structure of an orogenic belt, Tectonics, 8, 23-39.

Christensen N.I. (1979) Compressional wave velocities in rocks at high temperatures and pressures, critical thermal gradient, and crustal low-velocity zones, J. geophys. Res., 84, 6849-6857.

Christensen N.I. and Crosson R.S. (1968) Seismic anisotropy in the upper mantle, Tectonophys., 6, 93-107.

Christensen N.I. and Szymanski D.L. (1988) Origin of reflections from the Brevard foult zone, J. geophys. Res., 93, 1087-1102.

Cook F.A., Albaugh D.S., Brown L.D. and Hatcher R.D. (1979) Thin-skinned tectonics in the crystalline southern Appalachians; COCORP seismic reflection profiling of the Blue Ridge and Piedmont, Geology, 7, 563-567.

Crampin S. (1985) Evaluation of anisotropy by shear-wave splitting, Geophysics, 50, 142-152.

Crosson R.S. and Lin J.W. (1971) Voigt and Reuss prediction of anisotropic elasticity of dunite, J. geophys. Res., 76, 570-578.

Fountain D.M., Hurich C.A. and Smithson S.B. (1984) Seismic reflectivity of mylonite zones in the crust, Geology, 12, 195-198.

Jones T.D. and Nur A. (1984) The natureof seismic reflection from deep crustal fault zone, J. geophys. Res., 89, 3153-3171.

Kern H. (1982) Elastic-wave velocity in crustal and mantle rocks at high pressure and temperature: the role of the high-low quartz transition and of dehydration reactions, Phys. Earth Planet. Int., 29, 22-23.

Kern H. (1990) Laboratory seismic measurements: an aid in the interpretation of seismic field data, Terra Nova, 2, 617-628.

Kern H. and Richter A. (1981) Temperature derivatives of compressional and shear wave velocities in crustal and mantle rocks at $6 \mathrm{Kbar}$ confining pressure, J. Geophys., 49, 47-56.

Kern H. and Schenk V. (1988) A model of velocity structure beneath Calabria, southern Italy, based on laboratory data, Earth Planet. Sci. Letts, 87, 325-337.

Kern H. and Wenk H.R. (1990) Fabricrelated velocity anisotropy and shear wave splitting in rocks from Santa Rosa mylonite zone, California, J. geophys. Res., 95, 11213-11223.

Lloyd G.E., Cockayne B. and Jones D.W. (1981) Selected-area electron channelling patterns from geological materials: specimen preparation and representation of patterns and applications, Can. Miner., 19, 505-518.

Lloyd G.E., Ferguson C.C. and Law R.D. (1987) Discriminatory petrofabric analysis of quartz rocks using SEM electron channelling, Tectonophys., 135, 243-249.

Mainprice D. (1990) A FORTRAN program to calculate seismic anisotropy from the lattice preferred orientation of minerals, Computers \& Geosciences, 16, 385-393.

Mainprice D., Casey M. and Schmid S. (1990) The seismic properties of alpine quartz mylonites determined from the orientation distribution functions, $\mathrm{Mem}$. Soc. géol. Fr., 156, 85-95.

Mainprice D. and Nicolas A. (1989) Development of shape and lattice preferred orientations: applications to the seismic anisotropy of the lower crust, J. Struct. Geol., 11, 175-189. 
McDonough D.T. and Fountair D.M (1968) Reflection characteristics of ₹ mylonite zone based on compressionz? waves velocities of rock sampies. Geophys. J., 93, 547-558.

McSkimin H.J., Anreatch J.R. and Thurston R.N. (1965) Elastic moduli of quart\% versus hydrostatic pressure at $25^{\circ}$ and $-195.8^{\circ} \mathrm{C}$, /. Appl. Phys., 36, 1624-1632.

Nicolas A., Polino R., Hirn A. and Nicolich R. (1990) ECORS-CROP traverse and the deep structure of the western Alps: a synthesis, Mérn. Soc. geol. France, 156, 15-27.

Passchier C.W. (1982) Mylonitic deformation in the St-Barthélémy massif, French Pyrénées, with emphasis on the generation relationship between ultramylonite and pseudotachylite, A.G.U. Pap. Geol., 1 (16), 1-173.

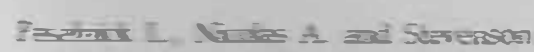
$P a, F=$ Telocily anisotropy in a

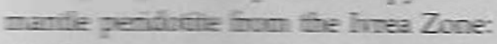
Applicabium II upper mantile aniso-

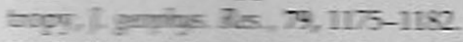

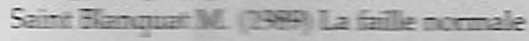

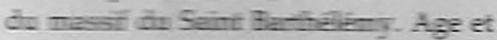

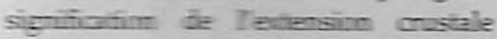

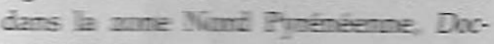

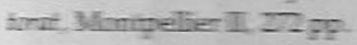

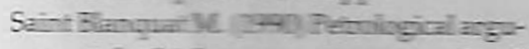
mert for high urmpenature extensinnal deformalom in the Pinenean Warscan

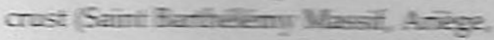

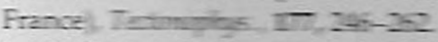

Schmid SM and Carm ML Iobe Cour-

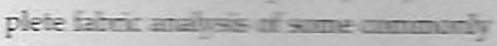

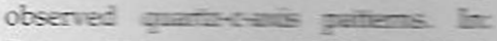

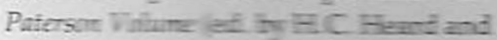

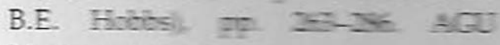
Monogr, Washingur.
Schmidt N.H. and Olsen N.O. (1989) Computer-aided determination of crysial-lattic orientation from electronchanelling patterns in the SEM, Can. Miner., 27, 15-22.

Seront B., Mainprice D. and Christensen N.I. (1992) A determination of the 3-dimensional seismic properties of an anorthosite - Comparison between values calculated from petrofabric and direct laboratory measurements, J. gerpirys. Res., submitted.

Silver P.G. and Chan W. (1988) Implicajons for continental structure and evolution from seismic anisotropy, Vะ⿱亠䒑䶹т, 335, 34-39.

Vaughan M.T. and Guggenheim S. (1986) Fiasticity of muscovite and its relationship to crystal structure, J. geophys. Re's., 91, $\div 65 \mathrm{~J}-4664$. 